\title{
Development of Learning Models Make A Match Assisted Media Puzzle to Improve Thinking Skills of Class Fourth Elemetary School Studests
}

\author{
Fu'adatul Fithroh $^{1}$, Murtono $^{2}$, Sri Utaminingsih ${ }^{3}$ \\ \{fuadatulfithroh@gmail.com¹, murtono@umk.ac.id², sri.utaminingsih@umk.ac.id ${ }^{3}$ \} \\ ${ }^{1,2,3}$ Faculty of Teaching and Education, Universitas Muria Kudus Gondang \\ Manis PO. BOX 53 Bae, Kudus, Central Java, Indonesia \\ Phone (+62291) 438229, Fax (+62291)437198
}

\begin{abstract}
This development research aims to describe the application of the Make a Match learning model, the development of the Make a Match learning model assisted by Puzzle media, the effectiveness of the Make a Match learning model assisted by the Puzzle media to improve the critical thinking skills of fourth grade students in elementary schools. Make a Match learning model is a fun learning model where in the learning process students are free to look for the question cards and answer cards they need. Puzzle is an image that is divided into pieces of images that aim to hone the power of thought, practice patience, and familiarize the ability to share. The puzzle media is expected to be able to attract students' attention and make it easier for students to understand teaching materials without having to depend on the presence of the teacher in class. Critical thinking skills are an activity through thinking about ideas or ideas related to the concepts given or problems presented. This type of research used in this research is Research and Development (R \& D) which is used to produce a particular product, and test the effectiveness of the product. steps in this research and development, including potential problems, data collection, product design, design validation, design revisions, product trials, product revisions, product trials, product revisions, and mass production. Data sources can be taken from students, teachers, and experts. The techniques used to collect data are interviews, observation, questionnaire and documentation.
\end{abstract}

Keywords: Make a Match Learning Model, Puzzle media, critical thinking skills

\section{INTRODUCTION}

Education is the most important to develop the power of the understanding and critic pattern for all learners. The decision of the succession of the nation's qualities is the impact of an educational position. An education is occupied by the development and progress for the nation to the nation for the nation for the nation to the growingness. For can not grow and progress, a education is not only the part of the party, but all parties to be involved. Both the participants, the educators, governments, and society.

So many problems of education in our nation, Indonesia. One of the problems in the teaching and learning process is not an innovation or update in terms of learning, a model of learning. Soekamto (in Shoimin, 2014:23) suggests that the learning model is a conceptual frame that describe systematic procedures in organizing learning experience to achieve certain learning objectives, and serves as guidelines for learning designers and teachers in planning teaching learning activities.

This most learning in schools still uses a pure learning model, has not developed with innovation and variations new, even the most educators in teaching rarely use the learning model. They just rely on the pursuit of the target material to be achieved without thinking learning process and students' understanding of the material being taught. Therefore, it is necessary to develop a learning model, one of them is the Make a Match learning model that can help the learning process so that learning is more varied.

Make a Match learning model is a learning model where students are required to look for pairs of cards that are suitable for pairing on the cards that they get. The teacher acts more as a 
facilitator in the classroom. In this case, it is necessary to arrange classrooms in such a way as to support cooperative learning, in addition to the decision making by teachers in class structuring, it must also be adapted to the conditions and situations of the class and school. According to Sani (2014:196) the steps of the Make a Match learning model are as follows.

1. The teacher prepares several cards that contain several concepts or topics that have been discussed before.

2. Each student gets one card, one gets a question card and one gets an answer card.

3. Students who get a question card think of answers from the card held, while those who get an answer card think of relevant questions.

4. Students look for pairs who have cards that match the card.

5. The teacher gives a value (points) for each pair of students who can match the card before the specified time limit.

6. After one round of cards shuffled again so that each student gets a different card than before.

7. The teacher rewards groups that have the highest score, then guides students to make conclusions.

According to Huda (2014:252) the steps of the Make a Match learning model are as follows.

1. The teacher conveys material or gives assignments to students to study material at home.

2. Students are divided into 2 groups, for example group A and group B, both groups are asked to come face to face.

3. The teacher distributes question cards to group A and answer cards to group B.

4. The teacher tells the students that they must find / match the cards held by other group cards. The teacher also needs to convey the maximum time limit he gives them.

5. The teacher asks all members of group A to look for their partners in group B. If they have found their respective partners, the teacher asks them to report themselves to him. The teacher records them on the prepared paper.

6. If time is up, they must be notified that time is up. Students who have not found a partner are asked to gather alone.

7. The teacher calls one pair for a presentation. Other couples and students who do not get a partner pay attention and respond whether the couple is suitable or not.

8. Finally, the teacher gives confirmation about the truth and suitability of the questions and answers from the pair giving the presentation.

9. The teacher calls out to the next pair, and so on until all pairs make presentations. Furthermore, Murtono (2017:76) explained the steps of the Make a Match learning model as follows.

1. The teacher prepares a question card and answer card.

2. The teacher divides the class community into three groups. The first group of card bearers contains question cards. The second group of card bearers contains answer cards. The third group is the assessment group.

3. The teacher sets the position of the group in the shape of a U.

4. The teacher sounds a whistle as a sign so that the first group and the second group move together they meet, looking for a suitable question-answer pair.

5. The pair that has been formed must show the question-answer to the assessment group.

Shoimin (2014:99) suggests the Make a Match learning model has the following advantages and disadvantages.

a. The advantages of the learning model Make a Match

1. An atmosphere of excitement will grow in the learning process.

2. Collaboration between students is dynamic.

3. The emergence of mutual cooperation dynamics that are evenly distributed throughout the students.

b. The disadvantages of the learning model Make a Match

1. Required guidance from the teacher to do learning.

2. The class atmosphere became noisy so that it could disturb other classes.

3. The teacher needs to prepare appropriate materials and tools.

Huda (2014:253) suggests the Make a Match learning model has the following advantages and disadvantages. 
a. The advantages of the model Make a Match

1. Can increase student activity, both cognitive and physical.

2. Because there are elements of the game, this model is fun.

3. Increase student understanding of the material being studied and can increase student motivation.

4. Effective as a means of training the courage of students to perform.

5. Effectively train student discipline to value time for learning.

b. Weaknesses of the learning model Make a Match

1. If this strategy is not well prepared, a lot of time will be wasted.

2. At the beginning of the application of the model, many students will be embarrassed to partner with the opposite sex.

3. If the teacher does not direct it well, there will be many students who are not paying attention to the pair presentation.

4. Teachers must be careful and wise when giving punishment to students who do not get a partner, because they can be embarrassed.

5. Using this model continuously will lead to boredom.

In a learning model there is a need for learning media that can help students to improve their critical thinking skills. Learning media are all things that can be used to channel messages and stimulate the learning process of the learner (Aqib 2013: 50). According to Rossi 'and Breidle (in Sukardi 2012:163) argued that learning media are all tools and materials that can be used to achieve educational goals. However, media is not only in the form of tools or materials, but also other things that allow students to gain knowledge. In line with Gerlach's opinion (in Sukardi 2012:163), the media itself includes people, materials, equipment, or activities that create conditions that enable students to acquire knowledge, skills and attitudes. According to Sanjaya (2008: 205) stated that the media is not only an intermediary tool such as TV, radio, slides, but includes people or humans as a source of learning or also in the form activities such as discussions, seminars, field trips, simulations and so on are conditioned to increase knowledge and insight, change students' attitudes, or to add skills.

Sanjaya (2008:209) argues that learning media has the following benefits.

1. The media can overcome the limitations of the experience students have.

2. The media can overcome the limitations of the experience students have.

3. Media can enable direct interaction between participants and the environment.

4. Media can produce uniform observations.

5. The media can instill the basic concepts that are true, real, and right.

6. Media can arouse motivation and stimulate participants to learn well.

7. The media can arouse new desires and interests.

8. The media can control the speed of student learning.

9. The media can provide a holistic experience from concrete to abstract things.

Aqib (2013:51) argues that learning media has the following benefits.

1. Uniform delivery of material.

2. Clearer and more interesting learning.

3. The learning process is more interaction.

4. Time and energy efficiency.

5. Improve the quality of learning outcomes.

6. Learning can be done anytime and anywhere.

7. Cultivating a positive attitude towards learning towards learning processes and materials.

8. Increasing the role of teachers in a more positive and productive direction.

Sukardi (2012:169) suggests that learning media have the following benefits.

1. Capture an object or certain events.

2. Manipulate certain circumstances, events, or objects.

3. Add passion and student motivation to learn.

Sanjaya (2006:211) argues that the classification of instructional media is as follows.

1. Judging from its nature, the media can be divided into (1) Auditive media, (2) Visual media, and (3) Audiovisual media, which is a type of media that in addition to contains sound elements also contains elements of images that can be seen. 
2. Judging from the ability of its scope, the media can also be divided into (1) Media which have broad and simultaneous coverage such as radio and television. (2) Media that have limited coverage by space and time such as flim slides, films, videos, and so on.

3. Judging from the way or technique used, the media can also be divided into (1) Projected media, such as films, slides, film strips, transparencies, etc., and (2) Media that is not projected, such as images, photographs, paintings, radio, and so on.

Another opinion expressed by Rudy Brets (in Sanjaya, 2008:212) believes that there are seven media classifications as follows.

1. Audiovisual motion media, such as sound films, video tapes, tv films.

2. Audiovisual media is silent, like a soundtrack.

3. Sparkling audio, like a distant distant voice.

4. Motion visual media, such as silent films.

5. Silent visual media, such as print pages, photos, microphones, mute slides.

6. Audio media, such as radio, telephone, audio tapes.

7. Print media, such as books, modules, independent teaching materials.

According to Khomsoh (in Permana, 2017:2) argues that Puzzle is an image that is divided into pieces of images that aim to hone the power of thought, practice patience, and familiarize the ability to share. The puzzle media is expected to be able to attract students' attention and make it easier for students to understand teaching materials without having to depend on the presence of the teacher in class (Umar et al, 2015:2).

According to Munir (in Umar et al, 2015:2) the advantages of puzzle media are as follows.

1. The learning system is more innovative and interactive.

2. Educators will always be required to be innovative in finding creative breakthroughs in learning.

3. Able to combine text, images, audio, music, animated images or videos in a single unit that supports each other in order to achieve goals. Learning.

4. Adding motivation for students during the learning process until the desired learning objectives are obtained.

5. Being able to visualize material that has been difficult to explain just by conventional explanations or props.

6. Train students to be more independent in gaining knowledge.

We need to know, successful learning is where students can think critically about learning that takes place. According to Surya (2016:123) critical thinking is one of the cognitive strategies in solving more complex problems and demanding higher patterns. Critical thinking is one form among various types of thinking. Meanwhile, according to Susanto (2016:121) critical thinking is an activity through the way of thinking about ideas or ideas related to the concept given or the problem presented. Another opinion, according to Saptono (2011:123), is that critical thinking is an educational thought and work that seeks to challenge an unjust social reality, which aims to find and develop new models of life that are more just. Further explained by Zuchdi (2009:125) argues that in critical thinking at first it is necessary to practice expressing these concepts by thinking deeply, so that they can master them well.

Susanto (2016:125), explained five indicators of each aspect of critical thinking related to the subject matter, namely (1) Providing simple explanations, (2) Building basic skills, (3) Concluding, (4) Providing further explanation, and (5) Managing strategies and tactics. Critical thinking skills of students need to be developed starting from elementary school through habituation in learning, habituation in the learning process will improve students' critical thinking skills. One of the learning materials that needs to be inserted is the students' critical thinking skills in learning, namely the Indonesian Language and Social Sciences subjects in Theme 1 The Beauty of Togetherness in grade IV Elementary School.

Based on observations and interviews conducted by researchers to several teachers, the researchers came to a conclusion that in the learning process in class IV that some teachers only teach it, do not use the learning model. Even the media someties they rarely apply in learning. The teacher has not been able to invite students to play an active role during the learning process, which causes students to not be able to develop their critical thinking processes. As a result students feel bored and teaching and learning activities are less effective, which is caused by the 
absence of an innovation and creativity done by the teacher in learning and the absence of a learning medium that students should get so that they can easily capture the material described by the teacher.

Related to this problem, it is necessary to develop an interesting learning model with the help of a media to improve students' critical thinking skills. Through the development of learning models that are applied can make students more able to capture the material delivered by the teacher and hopefully learning can be fun because learning while playing.

Based on the description above, researchers will conduct a research and development under the title "Development of Learning Models Make a Match Assisted by Media Puzzles to Improve Critical Thinking Processes of Class IV Elementary School Students".

\section{METHOD}

This type of research used in this research is Research and Development (R \& D). According to Borg \& Gall (in Setyosari, 2013:276) suggested that development research is a process used to develop and validate educational products. Another opinion according to Sugiyono (2015:07) Research and Development (R \& D) is a research method used to produce certain products, and test the effectiveness of these products. The purpose of this research development is to develop a Make a Match learning model assisted by Puzzle media to improve skills critical thinking grade IV elementary school students. This research was conducted in class IV SD 1 Piji and SD 7 Cendono, as an experimental group and SD 1 Lau and SD 2 Piji as a control group in Dawe District, Kudus Regency. Data collection techniques in research and development is done through Observation, Interview, Questionnaire/Questionnaire, and Documentation.

Observation is used by observing learning using the Make a Match learning model assisted by Puzzle media to improve critical thinking skills by teachers and grade IV elementary school students in Dawe District, Kudus Regency. The interview in this study aimed at teachers and fourth grade students of elementary schools. The questionnaire / questionnaire in this study was used to collect assessment data regarding the learning model. Data collection about the effectiveness of the Make a Match learning model aimed at teachers and students. Then the documentation method is carried out to strengthen the data obtained in observation. To provide a concrete picture of student group activities and illustrate the atmosphere of the classroom when learning activities take place by using the Puzzel media a Make a Match learning model in improving students' critical thinking skills photo documents are used.

The design of this research and development can be described in the following chart. 


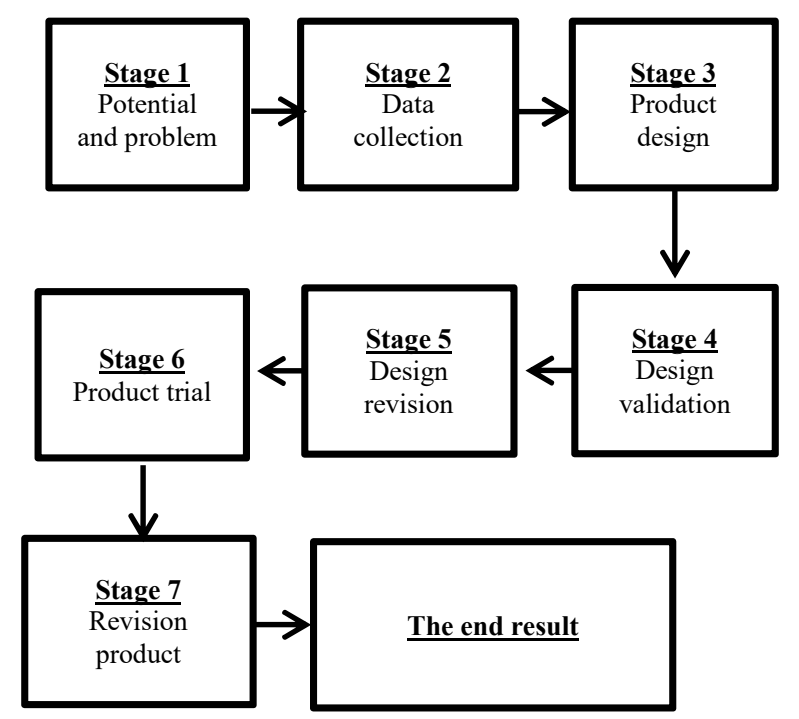

Gambar. Bagan Prosedur Penelitian

\section{RESULTS AND DISCUSSION}

The results of observations and interviews note that students need the development of a learning model so that learning can be more interesting and enjoyable. Then from the teacher's point of view states the development of learning model is very necessary in the world of education so that learning is more interesting and not monotonous, with the development of learning models students can be motivated to be active in learning, while students can improve critical thinking skills

Some of the findings that researchers found when conducting observations and interviews include teachers only teaching it, not using the learning model. Even mediapun sometimes they rarely apply in learning. The teacher has not been able to invite students to play an active role during the learning process, which causes students to not be able to develop their critical thinking processes. As a result students feel bored and teaching and learning activities are less effective, which is caused by the absence of an innovation and creativity done by the teacher in learning and the absence of a learning medium that students should get so that they can easily capture the material described by the teacher. Related to this problem, it is necessary to develop an interesting learning model with the help of a media to improve students' critical thinking skills. Through the development of learning models that are applied can make students more able to capture the material delivered by the teacher and hopefully learning can be fun because learning while playing.

Table 1. Analysis of the need for a make a match learning model assisted by puzzle media on students' critical thinking skills

\begin{tabular}{|l|l|l|c|c|c|}
\hline No & \multicolumn{2}{|c|}{ Group } & $\begin{array}{c}\text { Aver } \\
\text { age }\end{array}$ & $\begin{array}{c}\text { Perce } \\
\text { ntage }\end{array}$ & Criteria \\
\hline \multirow{2}{*}{1.} & \multirow{2}{*}{$\begin{array}{l}\text { Experi } \\
\text { ment }\end{array}$} & SD 1 Piji & 67 & $67 \%$ & Enough \\
\cline { 3 - 6 } & $\begin{array}{l}\text { SD 7 } \\
\text { Cendono }\end{array}$ & 65 & $65 \%$ & Enough \\
\hline \multirow{2}{*}{2.} & \multirow{2}{*}{ Control } & SD 1 Lau & 65 & $65 \%$ & Enough \\
\cline { 3 - 6 } & & SD 2 Piji & 65 & $65 \%$ & Enough \\
\hline
\end{tabular}


Based on the table above the critical thinking value of the Indonesian language and IPS lessons in SD 1 Piji as an experiment group obtained a classic average value of 67 with a percentage of $67 \%$ with enough criteria, then in SD 7 Cendono as the Control group obtained the average classical value of 65 with a percentage of $65 \%$ with enough criteria. While the average value of critical thinking in Indonesian language and IPS lessons in SD 1 Lau as the control group obtained the average classic value of 65 with $65 \%$ percentage with enough criteria. Then in SD 2 Piji as the control group obtained the average classic value of 65 with a percentage of $65 \%$ with enough criteria. Viewed from the average classic value in the experiment and control group can be said that the student's thinking critical skills are still low and needed a development to improve the critical thinking skills of students.

Based on the table above the As for some research relevant to these research and development, including research and development conducted by research is done by the authorya and pujiututik (2017) in its research entitled "Development of Group Model Investigation Media Video Story The subject of the environmental balance to improve the critical thinking of students". This study aims to describe the feasibility of learning devices and improvement of learning devices and improved critical thinking skills of students through the development of learning group of Group Investigation (GI). The results showed that the eligibility of learning devices of $83.529 \%$ are included in the category is very valid. The value of pre-test tests of critical thinking skills are completed by the percentage of $47 \%$, while the value of the post-test result of the test of the critical thinking skill is completed the percentage of $86 \%$. N-gain shows 0.75 indicates that the increase of the critical thinking ability that students are included experiencing a higher increase of students.

The results of the research conducted by Utomo and Noortjahja (2014) in his research entitled "Development of the model model of Teams Games Tournaments-based Literacy-based in the primary school." This study aims to determine the feasibility, student learning, and student response to the learning model developed. The results of the study are instructed, that the development of the device is by decrease and the teacher declares that the development of the device and has the decent for the development of the device and the teacher declare that the development of the device is decent to use in learning activities with the percentage of learning by the percentage of the $87 \%, 1.2 \%$, and $84 \%$, and $84 \%$ students. Student learning results are completed in $8 \%$ and not invented $17 \%$. Positive student response to learning tools that have been developed with percentage $78.2 \%$. From above the exposure to the development of learning Magnuary Magnu Puzzle to improve the critical thinking skills of classroom IV elementary school students are needed in supporting the learning process and improving the student's thinking critical skills.

\section{CONCLUSION}

Based on the results and discussions that have been described on the development of learning make a make of a Mag for Mary puzzle in improving the critical thinking skills of the students of class IV, it can be taken conclusions that the development model of make a match assisted media puzzle in increasing critical thinking skills Student students IV level of high school effective in improving student's critical thinking skills. The development of learning critical thinking of students. The development of learning critical thinking of students. The development of learning methods of making a matuction of puzzle media is needed by the teacher in providing varied learning experience and fun so students are interested, active, and motivated to follow the learning in class.

Based on the conclusion, then the suggestion can be submitted as follows (1) the teacher is expected to develop learning model in learning activities, and (2) Media Puzzles can be used teachers in conveying learning material, especially on theme 1 beautifulness together in class IV.

\section{REFERENCES}

Aqib, Zainal. 2013. Model-Model, Media, dan Strategi Pembelajaran Konstektual (Inovatif). Bandung: PT Yrama Widya. 
Awaliya, Sofiyati dan Pujiastutik, Hernik. 2017. Pengembangan Model Pembelajaran Group Investigation Media Video Story Pokok Bahasan Keseimbangan Lingkungan Untuk Meningkatkan Berpikir Kritis Siswa. Volume 6, Nomor 2, ISSN: 2252-6897. Hal.1-5.

Huda, Miftahul. 2014. Model-model Pengajaran dan Pembelajaran: Isu-isu Metodis dan Paradigmatis. Yogyakarta: Pustaka Pelajar.

Murtono. 2017. Merencanakan dan Mengelola Model-Model Pembelajaran Inovatif (Student Center Learning). Ponorogo: Wade Group.

Permana, Galih dan Haryudo, Subuh Isnur. 2015. Pengembangan Model Pembelajaran Berbasis Masalah Menggunakan Software Macromedia Flash 8 Pada Mata Pelajaran Instalasi Penerangan Listrik Untuk Meningkatkan Hasil Belajar Peserta Didik Di Kelas XI Tiptl SMK Negeri 1 Nganjuk. Volume 4, Nomor 3. Hal.1067-1073.

Sadiman. Dkk. 2012. Media Pendidikan Pengertian, Pengembangan, dan Pemanfaatannya. Depok: Raja Grafindo Persada.

Sani, Ridwan Abdullah. 2014. Inovasi Pembelajaran. Jakarta: Bumi Aksara.

Sanjaya, Wina. 2008. Perencanaan dan Sistem Pembelajaran. Jakarta: Kencana Prenada Media Grup.

Sanjaya, Wina. 2009. Penelitian Tindakan Kelas. Jakarta: Kencana Prenada Media Grup.

Saptono. 2011. Dimensi-Dimensi Pendidikan Karakter (Wawasan, Strategi, dan Langkah Praktis). Erlangga Group.

Setyosari, Punaji. 2013. Metode Penelitian Pendidikan dan Pengemabangan. Jakarta: Prenadamedia Group.

Shoimin, Aris. 2014. 68 Model Pembelajaran Inovatif dalam Kurikulum 2013. Yogyakarta: ArRuzz Media.

Sugiyono. 2015. Metodologi Penelitian Pendidikan. Bandung: Alfabeta.

Sukardi. 2012. Pembelajaran Menulis. Jakarta: UHAMKA Press.

Surya, Mohamad. 2016. Strategi Kognitif dalam Pembelajaran. Bandung: Alfabeta

Susanto, Ahmad. 2016. Teori Belajar dan Pembelajaran di Sekolah Dasar. Jakarta: Prenadamedia Group.

Umar, Syahwani. Dkk. 2015. Pengemangan Media Puzzle untuk Kecakapan Membaca Peta Buta Pada Siswa Sekolah Dasar. Volume 1. Nomor 2. Hal 1-12.

Utomo, Dani Prasetya dan Noortjahja, Andy. 2014. Pengembangan Model Pembelajaran Picture And Picture Terhadap Hasil Belajar Siswa Di Kelas X SMA Negeri 1 Kedungpring Pada Materi Alat Ukur Listrik. Volume 3, Nomor 1, ISSN: 2302-4496. Hal. 45-49.

Zuchdi, Darmiyati. 2009. Humanisasi Pendidikan (Menemukan Kembali Pendidikan yang Manusiawi). Jakarta: Bumi Aksara. 